\title{
直接基礎の上載圧による液状化抑制効果 \\ STUDY ON LIQUEFACTION SUPPRESSION EFFECT OF OVERBURDEN PRESSURE FROM SHALLOW FOUNDATIONS
}

\author{
小林治男*, 船原英樹**, 柴田景太 太 $^{* *}$, 長尾俊昌 $* * *$, 安 達俊夫***** \\ Haruo KOBAYASHI, Hideki FUNAHARA, Keita SHIBATA, \\ Toshiaki NAGAO and Toshio ADACHI
}

\begin{abstract}
The saturated ground just under shallow foundations tends not to liquefy due to the overburden pressure from the superstructure. But even in such cases, the structure can settle considerably due to liquefaction of the surrounding ground. Therefore this effect alone cannot be considered as a liquefaction countermeasure. On the other hand, a grid underground wall is widely used as a liquefaction contermeasure because of its shear deformation suppression effect. In this study, these two liquefaction suppression effect (overburden pressure and shear deformation suppression) are combined and tested in a centrifuge test. The tests results confirm that the overburden pressure from shallow foundations effectively suppresses liquefaction. This tendency is dominant when the contact pressure of the foundation is large and thickness of liquefaction layer is thin. Moreover, the grid underground wall effectively reduces the settlement of the shallow foundations.
\end{abstract}

Keywords : Liquefaction suppression, Shallow foundation, Overburden pressure, Grid underground wall, Centrifuge test 液状化抑制，直接基礎，上載圧，格子状地中壁，遠心力載荷実験

\section{1. 序論}

地震時に飽和した緩い砂地盤に生じる地盤の液状化現象は、平成 23 年 3 月 11 日東北地方太平洋沖地震においても、関東地方の湾岸 地域や旧河川の埋め立て地などで、広範囲に観測されており 1)、そ れによる被害状況も著しいため、大地震時に生じる特徽的事象とし て社会的にも広く認識されている。

液状化対策の手法には、(1)緩い砂の締固め、(2)粘着力の無い砂の 固化、(3)地下水位の低下、(4)格子状地中壁による地盤のせん断変形 の抑制 2)などがある。これらは、液状化発生に必要な複数の条件の うち、少なくとも一つを打ち消すという考え方に立脚しており、平 成 23 年 3 月 11 日東北地方太平洋沖地震においても、その有効性が 報告されている3)。しかしながら、地盤の液状化を抑制する対策は 多大な施工費が生じるため、比較的小規模な低層建物においては、 液状化対策を行わない場合も多く、より合理的な対策手法の開発が 求められている。

一方、飽和砂地盤の液状化強度は、初期有効拘束圧が大きい程大 きくなることは以前より知られており 4)、直接基礎直下地盤では上 載圧による液状化抑制効果により、液状化が起こりにくくなると考 えられる。Yoshimi らは、新潟地震の建物沈下の実測結果や直接基 礎構造物模型の振動実験結果より、建物重量による抑え効果、寸な
わち上載圧による液状化抑制効果を検証し、建物重量の抑え効果が 液状化抑制に有効なことを示している5)。また、飽和砂地盤の液状 化による直接基礎の沈下に関する遠心力載荷実験 6 (6),7)大型せん断 土槽を用いた振動実験 8 )においても、上載圧による液状化抑制効果 が観測されている。しかしながら、現状において建物重量の上載圧 による液状化抑制効果を利用した液状化対策手法は、実用化されて いない。これは、上載圧による液状化抑制効果の定量的な検討が殆 ぞされていないこと、簡易的評価手法が確立していないことおよび 直接基礎の上載圧により直下地盤の液状化が抑制されても基礎に大 きな沈下が生じること $\left.{ }^{6}, 7\right), 8$ によると考えられる。そのため、本研究 では、基礎に生じる大きな沈下に対する解決策として格子状地中壁 を併用することの有効性に着目した。

本論文では、飽和砂地盤上の直接基礎構造物を模擬した遠心力載 荷実験および直接基礎と格子状地中壁を模擬した遠心力載荷実験に ついて述べると共に、実験のシミュレーション解析結果と実験結果 の考察から、直接基礎による上載圧効果の簡易的な評価手法および 上載圧効果と格子状地中壁を併用した地盤における液状化抑制効果 に対する諸因子の影響について述べる。

\section{2. 直接基礎近傍の飽和地盤の地震時挙動}

\footnotetext{
* 大成建設株設計本部 シニアエンジニア・修士 (工学)

** 大成建設侏技術センター 主任研究員・博士 (工学)

*** 大成建設侏技術センター 研究員・修士 (工学)

**** 大成建設侏技術センター 主席研究員・博士 (工学

***** 日本大学理工学部 教授. 工博
}

Senior Engineer, Design Division, Taisei Corp., M. Eng.

Senior Research Engineer, Technology Center, Taisei Corp., Dr. Eng.

Research Engineer, Technology Center, Taisei Corp., M. Eng.

Chief Research Engineer, Technology Center, Taisei Corp., Dr. Eng.

Prof., College of Science \& Technology, Nihon Univ., Dr. Eng. 
前述の既往の直接基礎構造物模型の振動実験結果 5)、飽和砂地盤 の液状化時の直接基礎沈下挙動の把握を目的として行われた遠心力 載荷実験 6),7)や大型せん断土槽を用いた振動実験 8)などの実験結果 において、以下のことが確認されている。

- 地震時 (加振時) において、直接基礎直下地盤の過剩間隙水圧 比は、上載圧がない周辺地盤と比べ、抑えられる傾向にあり、 拘束圧による液状化抑制効果が認められる 5,6, 7),88。

・上載圧による液状化抑制効果は、基礎に近い浅い地盤ほど顕著 であり、深度が深くなれば効果が小さくなる傾向にある ${ }^{6), 7) 。 ~}$

筆者らが、飽和砂地盤上に建つ直接基礎建物の地震時挙動を検討 する目的で実施した遠心力載荷実験の実験結果においても、以上の ような傾向が認められている9）。下に、その遠心力載荷実験の実 験概要と実験より得られた結果および考察を示す。

\section{1 実験方法}

図 1 に試験体の概要と実験ケースを示す。円筒形のせん断土槽内 に地表面まで飽和させた地盤模型を作製し、その地表面上に正方形 のべた基礎を有する直接基礎建物模型を設置している。実験は、直 接基礎建物の地震時挙動を把握する目的で行ったものであり、加速 度、水圧、変位量を多数の測定点で計測しているが、本論では、図 示した構造物中心の直下および構造物から離れた周辺地盤部におけ る 3 深度の間隙水圧、模型基礎部および地表面と 3 深度の加速度、 模型上部に設置した測点をレーザー変位計で測定した基礎の沈下に ついての実験結果を用いる。実験模型の縮尺は 1/50（遠心加速度： $50 \mathrm{~g})$ としている。以下では、縮尺を考慮した実物換算した值で物 理量を示寸。地盤模型は、せん断土槽内に豊浦砂 $\left(\mathrm{e}_{\max }\right.$ : 0.992、 $\mathrm{e}_{\min }$ : 0.620 ）空中落下させた後、シリコーンオイル（動粘度 : $50 \mathrm{~mm}^{2} / \mathrm{s}$ ) で飽和させて作製した。実験は、地盤密度が密なケース、ゆるいケ 一スおよび密な層とゆるい層の二層ケースなどを実施しているが、 本論では相対密度が高いケース 1（相対密度 Dr：88\%）と相対密 度が低いケース 2 （相対密度 Dr : 49\%）の 2 ケースの実験結果に ついて示し考察する。円筒形のせん断土槽の大きさおよび梁さは、 直径 $20 \mathrm{~m}$ および深さ $15 \mathrm{~m}$ である。直接基礎の寸法は、一辺 $5 \mathrm{~m}$ の 正方形で、平均接地圧は約 $60 \mathrm{kN} / \mathrm{m}^{2}$ である。

入力地震動には、図 2 の人工地震波（臨海波 ${ }^{10}$ )、継続時間 120 秒、最大加速度 $310 \mathrm{~cm} / \mathrm{s}^{2}$ を約 0.4 倍の大きさを目標に調整、図 2 は 振動台の実測值）を用いた。

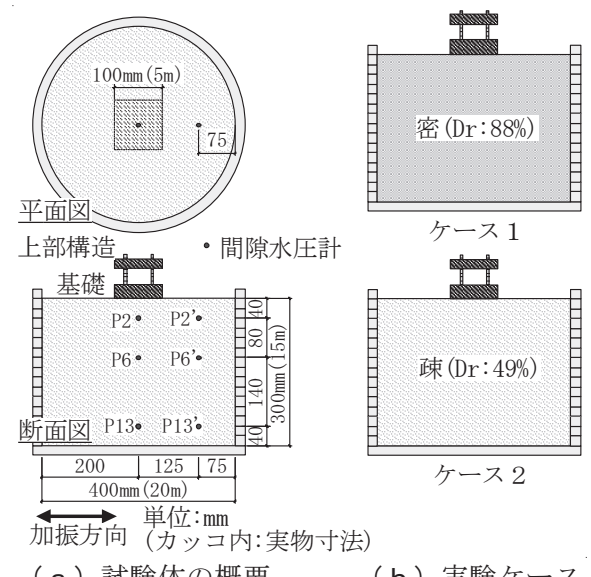

図 1 試験体の概要と実験ケース

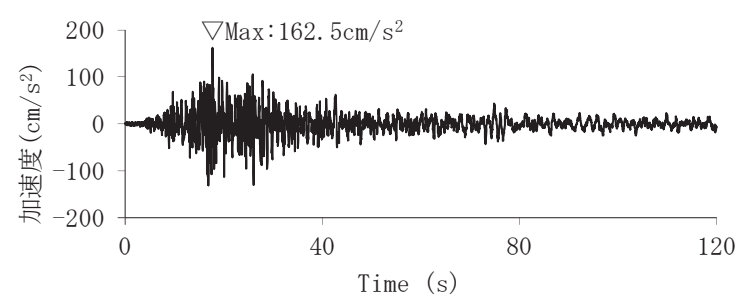

図 2 入力地震波

\section{2 実験結果}

以下に実験より得られた過剰間隙水圧比および基礎の沈下量の結 果とその考察を述べる。

\section{（1）過剩間隙水圧比}

計測した過剩間隙水圧を地中の鉛直応力（構造物重量による鉛直

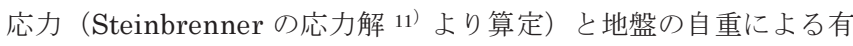
効土被り圧の和）で除して求めた過剩間隙水圧比の時刻歷を図 3 に 示寸。

基礎直下地盤の過剩間隙水圧比について見ると、深い深度の P13 (-13m) では、相対密度が低いケース 2 で過剩間隙水圧比が概ね 1 に達しており、液状化しているのに対して、相対密度が高いケース 1 では過剩間隙水圧比が 1 に達しておらず、液状化に至っていない。 一方、P2（-2m）と P6 (-6m) の浅い深度における過剩間隙水圧比 は、両ケースともに 1 に達しておらず、液状化に至っていない。P13

$(-13 \mathrm{~m})$ において液状化を確認した相対密度の低いケース 2 でさえ も、P2 (-2m) の過剩間隙水圧比は 0.4 程度にとどまっている。こ れは、直接基礎の上載圧により地中の拘束圧が増加し、過剩間隙水 圧比の上昇が抑制されたものと考えられる。そして、既往の実験結 果と同様に深度が浅い位置ほど過剩間隙水圧比の抑制効果が顕著で あり、深い位置では効果が小さいことが確認できる。また、相対密 度の程度によらず、その抑制効果が得られていることが分かる。

一方、周辺地盤の過剰間隙水圧比は、両ケースともいずれの深度 においても大きく上昇し、1 亿達するか 1 に近い值を示し、ほぼ全 域で液状化に達しており、直接基礎直下地盤の挙動と大きく異なる。
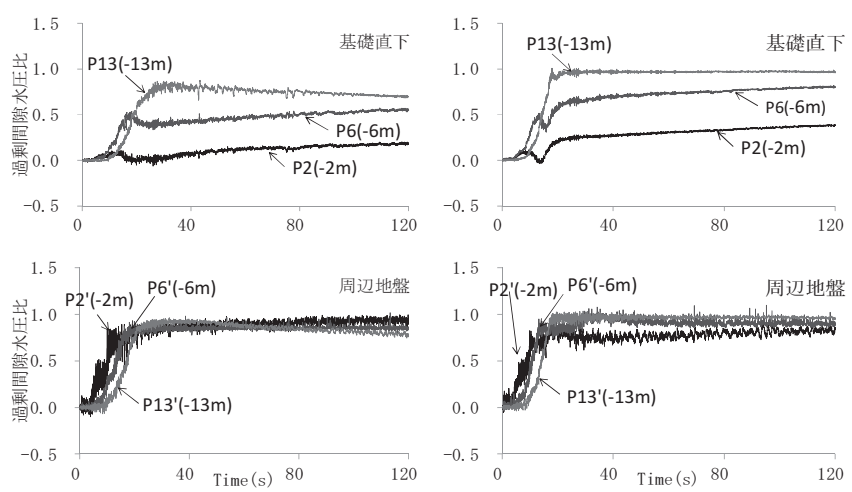

(a ) ケース $1(\mathrm{Dr}: 88 \%)$

(b) ケース $2(\mathrm{Dr}: 49 \%)$

図 3 過剩間隙水压比の時刻歴

\section{（2）基礎の沈下}

計測した基礎の沈下の時刻歴を図 4 に示す。基礎の沈下は、両久 一スともに地震動入力が終了した 120 秒時点でも増加傾向にあり、 
120 秒時点では、相対密度の低いケース 2 で $65 \mathrm{~cm}$ 程度、基礎直下 地盤に液状化が生じていない相対密度の高いケース 1 でも $15 \mathrm{~cm}$ 程 度の值を示した。

一方、図 5 に示した基礎の沈下量／最大沈下量と-6m の過剩間隙 水圧比（測定点：図 1 の $\mathrm{P} 6, \mathrm{P} 6^{\prime}$ ) との関係図から、基礎の沈下は、 基礎直下の過剰間隙水圧比よりも周辺地盤のそれが上昇しきった時 に増加する傾向にあり、本実験における基礎の沈下量の増加は、基 礎直下の過剩間隙水圧比よりも、周辺地盤の過剩間隙水圧比と相関 が高いことが分かり、周辺地盤の液状化発生が基礎の沈下に大きく 影響すると考えられる。このことから、基礎直下地盤の過剩間隙水 圧比の上昇が抑制されたとしても、基礎直下の地盤は、周辺地盤の 液状化に伴う剛性低下により、水平方向にはらみだし、基礎の沈下 が生じることが想定できる。

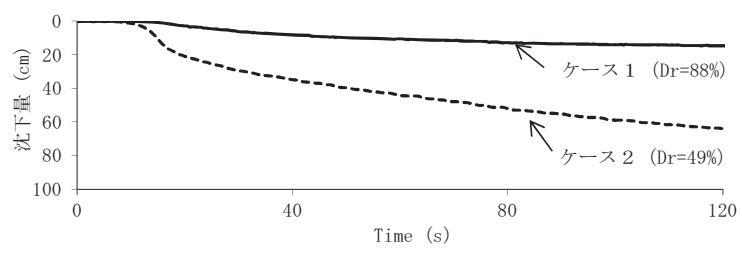

図 4 基礎の沈下の時刻歴

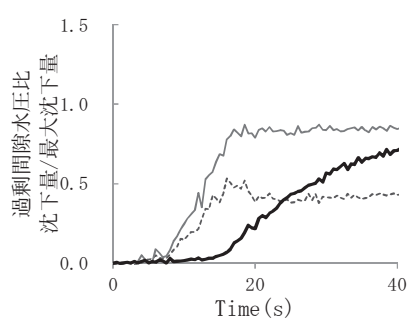

(a) ケース 1

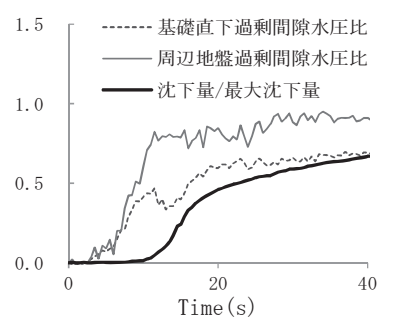

(b) ケース 2
図 5 基礎の沈下と過剩間隙水圧比（P6, P6’）の関係

\section{3 簡易評価手法の検討}

簡易的に液状化発生の危険度を評価する方法として、建築基礎構 造設計指針 12)（以下では、基礎指針と略す）などで示されている FL 法がある。FL 法については、各指針毎に係数などが異なるが、 基本的に液状化強度比（液状化抵抗比）（ $\tau_{1} / \sigma_{\mathrm{z}}^{\prime} ）$ を、ある地震の大 きさを想定した繰返しせん断応力比 $\left(\tau d / \sigma_{\mathrm{z}}{ }^{\prime}\right)$ で除した值が液状化 発生に対する安全率 FL と定義される。

ここで、液状化強度比が有効拘束圧によらず一定と考える 13) と液 状化強度比（ $\tau_{1} / \sigma_{\mathrm{z}}^{\prime} ）$ は、既往の評価式 12)で評価できる。

一方、繰返しせん断応力比 $\left(\tau d_{\mathrm{d}} / \sigma_{\mathrm{z}}{ }^{\prime}\right)$ は、既往の評価式では、建 物などの存在を考慮せず、深度毎の土被り圧による鉛直全応力に加 速度を乗じて、係数で補正したせん断応力より求めており、建物か ら地盤に伝達されるせん断応力は評価していない。

前述のように直接基礎建物などでは、直接基礎からの上載圧によ る液状化抑制効果が期待できるが、地盤に生じるせん断応力は直接 基礎から伝達される建物の慣性力によるせん断応力も加わるため、 従来評価されてきたせん断応力よりも大きな值となる可能性がある。 以上のことから、遠心力載荷実験のシミュレーション解析を行い、 直接基礎直下地盤における地震時せん断応力の検討を行った。

\section{（1）シミュレーション解析}

図 1 に示寸実験のシミュレーション解析は、二次元 FEM モデル を用いた。解析プログラムは、二相系の支配方程式に基づいた有効 応力解析コード DIANA-J214)に、土骨格の構成則として Stress-Density Model ${ }^{15)}$ を組込んだものを用いた。力学的境界条件 は、解析モデル底面を固定境界、側方は周期境界とした。図 6 に解 析モデル図を、図 7 に解析に用いた液状化強度曲線を示す。液状化 強度曲線は、Toki らの文献 16 )の豊浦砂の相対密度 $50 \%$ と $80 \%$ の液 状化強度に Stress-Density Model パラメータをフィッティングさ せた後、間隙比 $\mathrm{e}$ を調整して各ケースの液状化強度を設定した。間 隙比 e はケース 1 で $0.642(\mathrm{Dr}=88 \%)$ 、ケース 2 で $0.791(\mathrm{Dr}=49 \%)$ とし、静止土圧係数 $\mathrm{K}_{0}$ は、Okochi ら ${ }^{17)}$ による $\mathrm{K}_{0}=0.52 \mathrm{e}$ の関係よ り、ケース 1 で 0.334 、ケース 2 で 0.411 とした。

図 8 にケース 1 における過剩間隙水圧比の解析結果と実験結果の 比較を示す。解析結果は、過剩間隙水圧比を大きく評価する傾向に あるが、基礎直下の過剰間隙水圧比が周辺地盤よりも抑えられる傾 向にあることや基礎直下でも深くなるに従い過剩間隙水圧比が上が りやすい傾向にあることなど、実験結果を概ね再現している。

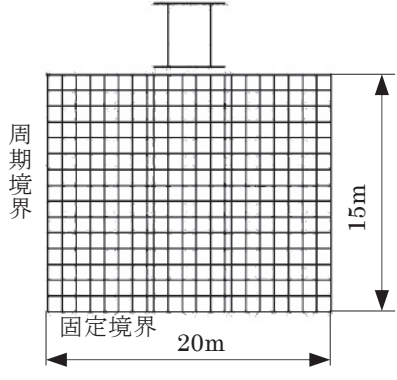

図 6 二次元 FEM モデル図

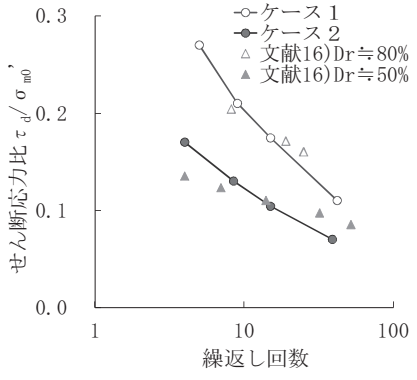

図 7 液状化強度曲線のモデル化 (初期平均拘束圧 $98 \mathrm{kN} / \mathrm{m}^{2}$ )

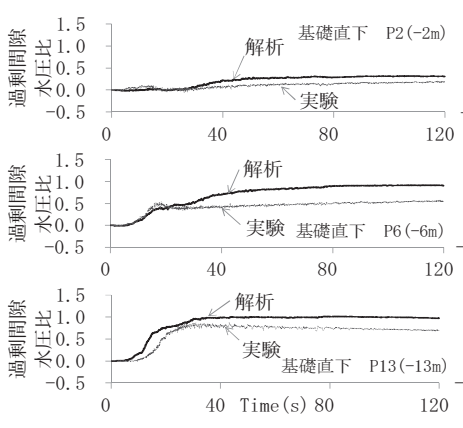

(a ) 基礎直下
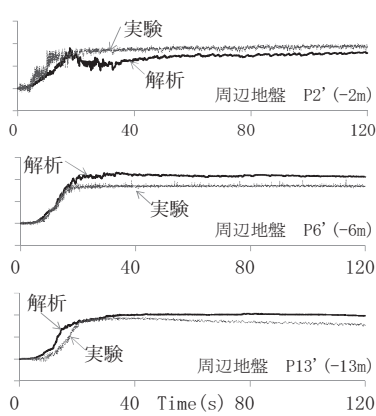

(b) 周辺地盤
図 8 過剩間隙水圧比時刻歴の解析結果と実験結果（ケース 1 )

\section{（2）加速度時刻歴からのせん断応力の推定}

建物慣性力による直接基礎からのせん断応力の伝達は、深さ方向 に基礎から離れるに従って広がり減少していく。ここでは、直接基 礎の地震時の地中せん断応力影響範囲面積を、図 9 に示すような深 度方向に半無限円錐で増加する面積と仮定して ${ }^{18)}$ 、直接基礎からの せん断応力を簡易的に評価する手法を試みる。

図 9 に直接基礎からの伝達せん断応力の影響範囲面積の概念図と 直接基䃈から伝達される各深度のせん断応力 $\tau \mathrm{Bi}_{\mathrm{B}}$ の算定式を示す。 


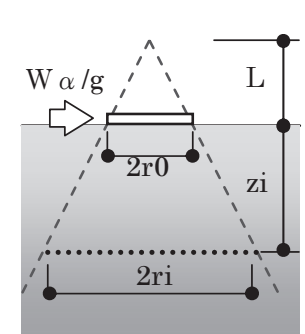

$\mathrm{r} 0=\sqrt{(\mathrm{B} \cdot \mathrm{H}) / \pi}$ $\mathrm{B}$ : 基礎幅、 $\mathrm{H}$ 基礎奥行 $\mathrm{L}=\pi \cdot \mathrm{r} 0 \cdot(2-\mathrm{v}) / 8$

$\mathrm{ri}=\mathrm{r} 0 \cdot(\mathrm{L}+\mathrm{zi}) / \mathrm{L}$

$\tau_{\mathrm{Bi}}=\mathrm{W} \cdot \alpha / \mathrm{g} /\left(\mathrm{ri}^{2} \cdot \pi\right)$

$\tau_{\mathrm{Bi}}:$ 基礎から伝達されるせん断応力

W: 建物重量、 $\alpha$ : 基礎の加速度

$\mathrm{g}:$ 重力加速度

図 9 直接基礎のせん断応力影響範囲面積とせん断応力算定式

地盤のポアソン比 $v$ 、建物重量 $\mathrm{W}$ および建物の応答加速度 $\alpha$ を設定 出来れば、直接基礎から伝達される各深度のせん断応力が求められ、 これに既往式と同様に求める地盤自体の慣性力によるせん断応力を 足し合せれば、直接基礎の地震時における各深度のせん断応力が求 められる。

シミュレーション解析結果の応答加速度時刻歴と地盤のせん断応 力時刻歴を用いて、式(4)を用いた直接基礎のせん断応力評価手法の 検証を行った。図 10 にケース 1 における解析結果のせん断応力時 刻歴と、応答加速度時刻歴（基礎および地中）から式(4)のせん断応 力評価手法を用いて推定したせん断応力時刻歷（式(4)で時刻毎に評 価した基礎から伝達されるせん断応力と、時刻毎に地盤の密度に水 平震度（各深度の加速度より算定）を乗じて深度毎に足し合せた地 盤自体の慣性力によるせん断応力の和）の比較を示す。比較は、主 要動が減少する 30 秒までを示している。式(4)を用いて応答加速度 時刻歴より推定したせん断応力時刻歴は、解析結果のせん断応力時 刻歴と良く一致しており、本評価手法で直接基礎の地震時の地盤せ ん断応力を概水評価できると考えられる。
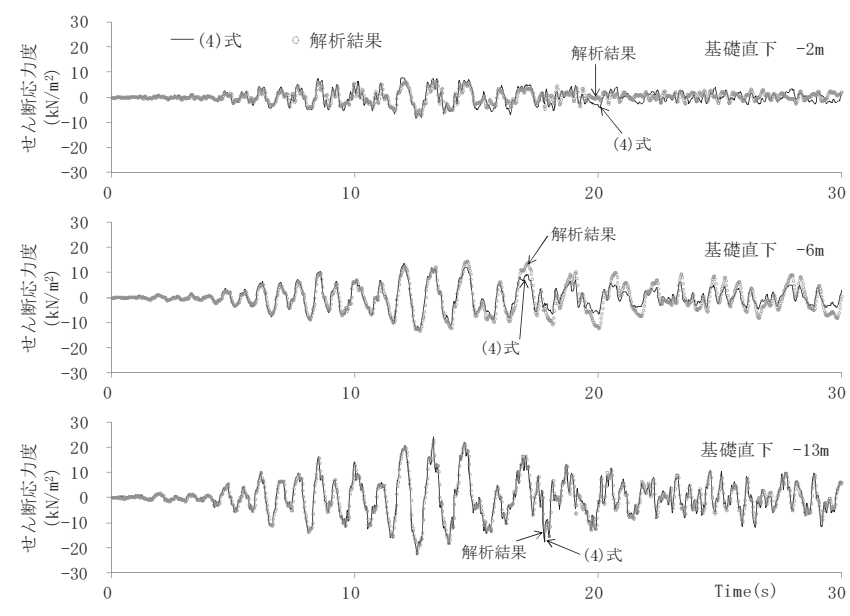

図 10 せん断応力時刻歴の比較

以上の結果から、直接基礎の簡易液状化判定用せん断応力比は、 式(5)で評価できると考えられる。

$\frac{\tau_{\mathrm{d}}}{\sigma_{\mathrm{z}}^{\prime}}=\gamma \mathrm{n}\left[\frac{\mathrm{W} \cdot\left(\alpha_{\mathrm{B}} / \mathrm{g}\right)}{\left(\mathrm{ri}^{2} \cdot \pi\right)}+\left(\alpha_{\mathrm{G}} / \mathrm{g}\right) \cdot \sigma_{\mathrm{z}} \cdot \gamma \mathrm{d}^{\prime}\right] / \sigma_{\mathrm{z}}^{\prime}$

ここに、 $\sigma_{\mathrm{z}}^{\prime}:$ 建物重量を考慮した各深度の有効上載圧、 $\gamma \mathrm{n}$ : 補正係数（基礎指針による $\left.{ }^{12}\right)$ )、 $\mathrm{W}:$ 建物重量、 $\alpha_{\mathrm{B}}$ : 基礎の応答加速度、 $\mathrm{g}$ : 重力加速度、 ri ：(3)式によるせん断応力伝達範囲面積の半径、 $\alpha_{\mathrm{G}}$ : 地表面加速度、 $\sigma \mathrm{Z}$ : 各深度の地盤のみの鉛直全応力 $\gamma \mathrm{d}$ ：補正係数（以下の本文参照）

図 11 に(5)式で求めた基礎直下地盤の等価繰返しせん断応力比 ((2)式におけるポアソン比は、 $\mathrm{K}_{0}=0.334 ， 0.411$ より、0.25，0.29 を用いた） と、解析結果の最大せん断応力比から求めた等価繰返し せん断応力比の比較を示寸 ( $\sigma$ z'は、Steinbrenner の応力解 ${ }^{11}$ )によ る)。図中、基礎指針のせん断応力比算定式 12) による結果（上載圧 未考慮）も併せて示す。両者ともに $\gamma \mathrm{n}=0.65$ として等価繰返しせん 断応力比を算定した。また、地盤自身の慣性力によるせん断応力の 深さ方向分布による補正係数 $\gamma \mathrm{d}$ は、基礎指針では $\gamma \mathrm{d}=1-0.015 \mathrm{Z}$

$(\mathrm{Z}$ : 深さ $(\mathrm{m}))$ としているが、これは主要な地震動による応答值の 平均值を直線で近似したものであり、梁くなるに従って実際の応答

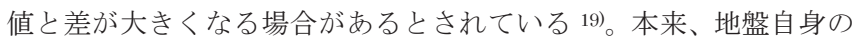
慣性力によるせん断応力の深さ方向分布は、土の性質や地震動の特 性によって異なる。図 11 では、 $\gamma \mathrm{d}^{\prime}=1-0.025 \mathrm{Z}$ と仮定し評価してい るが、一般的な算定式の評価としては更なる検討が必要であると考 えられる。なお、解析結果は有効応力解析による結果を用いている が、最大せん断応力および最大加速度は、周辺地盤等の過剩間隙水 圧比が上がりきって液状化が発生する前で生じており、液状化によ る影響は少ないと考えられる。

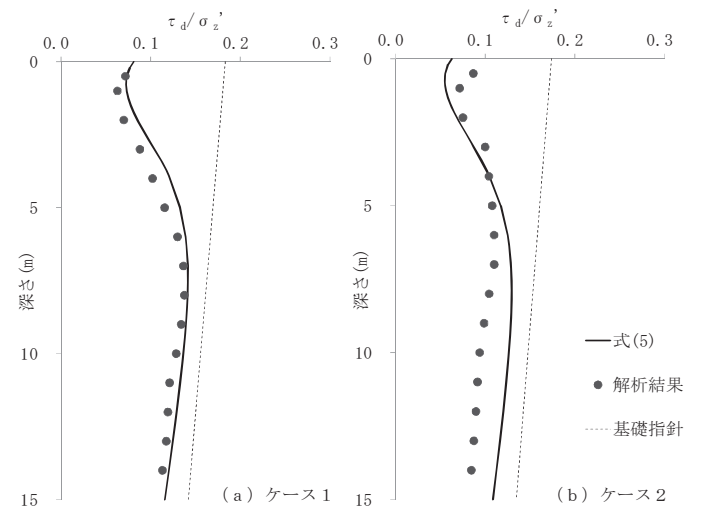

図 11 等価繰返しせん断応力比の比較 $\left(\gamma \mathrm{d}^{\prime}=1-0.025 \mathrm{Z}\right)$

図 11 より式(5)による等価繰返しせん断応力比は、解析結果と良 く一致しており、 $\gamma$ d'の評価に課題は残るものの、式(5)により直接 基礎の繰返しせん断応力比（ $\left.\tau_{\mathrm{d}} / \sigma_{\mathrm{z}}{ }^{\prime}\right)$ が評価できると考えられる。

図 12 に、実験時の計測最大加速度を用いて式(5)により評価した 繰返しせん断応力比 $\left(\tau \mathrm{d} / \sigma_{\mathrm{z}}^{\prime}\right)$ による FL 值と実験結果の過剰間隙 水圧比の関係を示す。液状化強度比は、図 7 で設定した液状化強度
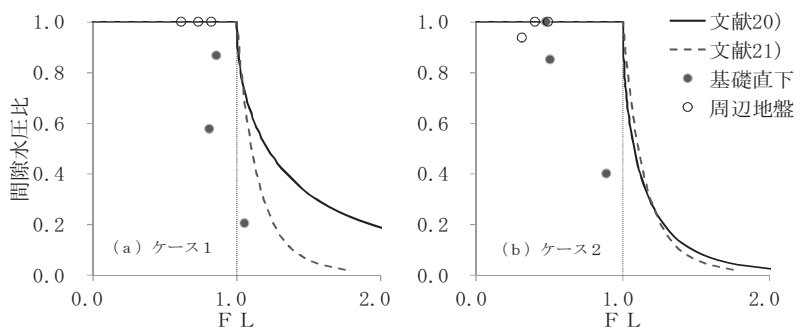

図 12 FL 值と過剩間隙水圧比（実験結果） 
曲線の繰り返し回数 15 回の強度比を、解析に用いた $\mathrm{K}_{0}$ を考慮して 原位置の強度に変換した值を用いた。図中、既往文献の過剩間隙水 圧比と FL 值との関係式 20),21) を併せて示した。算定結果の FL 值と 実験結果の過剩間隙水圧比は、FL 值が 1 を下回っても過剰間隙水 圧比が 0.6 以下となるなど FL 值が過小評価となっているが、FL 值 が小さいほど過剩間隙水圧比が大きくなる傾向は整合が取れている。

\section{3.上載圧による液状化抑制効果と格子状地中壁の併用}

前述のように、直接基礎の上載圧により過剩間隙水圧比の上昇を 抑制しても、基礎の沈下が過大となる可能性があり、また、周辺地 盤から基礎直下に過剩間隙水圧が伝搬され、二次的な液状化が生じ ることも否めないため、上載圧による液状化抑制効果単独による液 状化対策は難しいと考えられる。一方、Yoshimi ら ${ }^{5)}$ は、建物外周 に設置する地中壁の液状化対策工法に上載圧による抑え効果を併用 することで、基礎の沈下を抑制し、合理的に液状化対策が行えると 述べている。しかしながら、平面的に広い建物において、建物外周 部のみに地中壁を設けた場合では、せん断変形抑制効果が少なく、 建物中央部の深い位置で液状化が生じる可能性がある。これに対し 格子状に地中壁を設けることで、格子状地中壁の格子間の地盤のせ 几断変形抑制効果の付加も期待でき、基礎直下地盤が水平方向には らみだして基礎に過大な沈下が生じることを防ぐことが可能である。 また、周辺地盤の過剰間隙水圧が基礎直下の地盤に伝播して二次的 な液状化が生じることを、地中壁の遮水性で防ぐことが出来る。

以上のように、直接基礎の上載圧による液状化抑制効果と格子状 地中壁を併用することで、より合理的な液状化対策が可能と考えら れる。

そこで、直接基礎の上載圧と格子状地中壁の併用による液状化抑 制効果を確認するため、飽和地盤上の直接基礎と格子状地中壁を模 擬した模型を用いた遠心力載荷実験を実施した。

\section{1 実験方法}

本実験では、直接基礎の上載圧によって過剩間隙水圧比が抑制さ れ、かつ格子状地中壁の存在により直接基礎の沈下が抑制されるこ との確認が主要な目的である。

図 13 に実験模型と計測の概要を示す。せん断土槽中に、飽和砂 模型とアクリル製の格子状地中壁模型を設置し、直接基礎の上載圧 などをパラメータにして、50g の遠心場における振動台実験を行っ た。本実験では、想定した上載圧を格子間の地盤に確実に伝達させ るために、格子毎に独立した基礎模型を直接格子間の地盤地表面に 設置する方法とした。基礎模型と格子壁の間には、約 $1 \mathrm{~mm}$ のクリ アランスを設け過剩間隙水圧が消散できるように配慮した。また、 基礎模型下端と格子壁天端は、ほぼ同レベル上に設置した。

格子間隔が狭い場合に格子壁に摩擦力が作用し上載圧が格子内地 盤に十分に作用しない可能性があるが、格子壁に摩擦抵抗の小さい アクリル板を用いることで、その影響が小さくなるように配慮した。 地盤模型の作製では、せん断土槽内に豊浦砂 $\left(\mathrm{e}_{\max }\right.$ ：0.988、 $\mathrm{e}_{\min }$ ： 0.616）を相対密度 $60 \%$ となるように空中落下させた後、シリコー ンオイル（動粘度 : $50 \mathrm{~mm}^{2} / \mathrm{s}$ ) で飽和させた。

本実験における実験模型の縮尺は、1/50（遠心加速度：50g）と している。以下では縮尺を考慮し、実物換算した值で物理量を示す。

本実験における主なパラメータを表 1 に示す。直接基礎による上 載圧、地中壁の格子間隔および液状化層厚を主なパラメータとした。 直接基礎の上載圧については、 $0 \mathrm{kN} / \mathrm{m}^{2}$ (基礎模型なし)、30kN/m²、 $60 \mathrm{kN} / \mathrm{m}^{2}$ の 3 種類である。地中壁模型の加振方向の格子間隔は、 $3 \mathrm{~m}$ 、 $5 \mathrm{~m} 、 10 \mathrm{~m}$ の 3 種類である。液状化層厚（地中壁深さも同様）は、 $5 \mathrm{~m} 、 10 \mathrm{~m}$ の 2 種類とした。

また、地中壁の沈下抑制効果を確認するために、地中壁を設置し ない基礎のみの実験ケースを、液状化層厚 $10 \mathrm{~m}$ 、直接基礎の上載圧 $60 \mathrm{kN} / \mathrm{m}^{2}$ の条件下でのみ実施した。
地中壁のみ
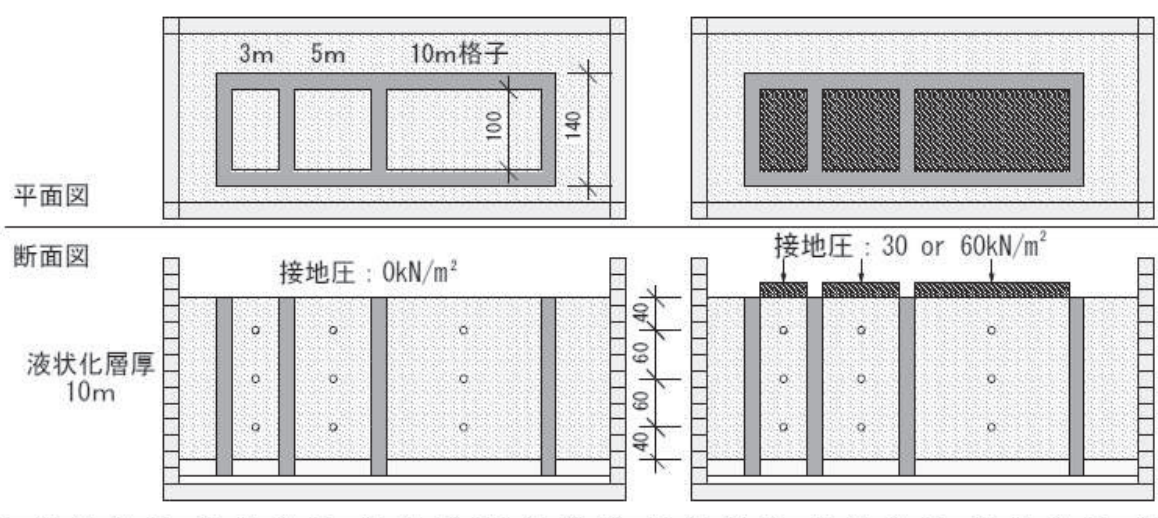

地中壁＋直接基礎

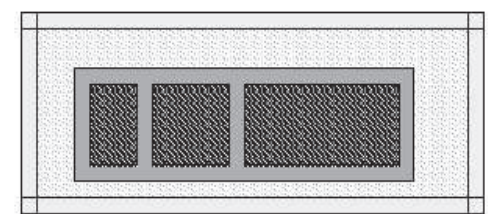

接地圧 : 30 or $60 \mathrm{kN} / \mathrm{m}^{2}$
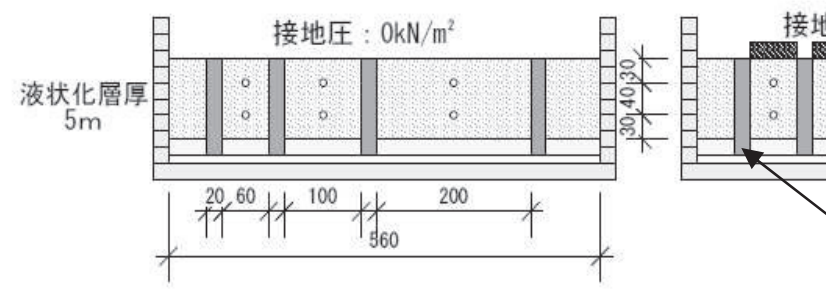

水圧計 | 変位計

図 13 実験模型と計測の概要 
入力地震動には、前章で示した直接基礎の遠心力載荷実験と同様 に図 2 の人工地震波 (臨海波 ${ }^{10}$ ) 、継続時間 120 秒、最大加速度 $310 \mathrm{~cm} / \mathrm{s}^{2}$ を約 0.4 倍の大きさに調整）を用いた。

表 1 実験におけるパラメータ

\begin{tabular}{|c|c|c|c|c|c|}
\hline \multirow{2}{*}{\multicolumn{2}{|c|}{$\begin{array}{c}\text { 基礎タイプ } \\
\text { 上載圧 }\end{array}$}} & \multirow{2}{*}{$\begin{array}{c}\text { 地中壁のみ } \\
0 \mathrm{kN} / \mathrm{m}^{2} \\
\end{array}$} & \multicolumn{2}{|c|}{ 地中壁＋直接基礎 } & 直接基礎のみ \\
\hline & & & $30 \mathrm{kN} / \mathrm{m}^{2}$ & $60 \mathrm{kN} / \mathrm{m}^{2}$ & $60 \mathrm{kN} / \mathrm{m}^{2}$ \\
\hline \multirow{2}{*}{$\begin{array}{c}\text { 液状化 } \\
\text { 層厚 }\end{array}$} & $10 \mathrm{~m}$ & 0 & $\begin{array}{c}\text { 上載圧 } 60 \mathrm{kN} / \mathrm{m}^{2} \sigma \\
\text { 試験体を再利用し } \\
\text { 再加振 }\end{array}$ & 0 & 0 \\
\hline & $5 \mathrm{~m}$ & $\begin{array}{c}\text { 上載圧 } 60 \mathrm{kN} / \mathrm{m}^{2} の \\
\text { 試験体を再利用し } \\
\text { 再加振 } \\
\end{array}$ & 0 & 0 & 未実施 \\
\hline & & \multicolumn{3}{|c|}{ 格子間隔：3m, $5 \mathrm{~m}, 10 \mathrm{~m}$} & 基礎幅: $3 \mathrm{~m}, 5 \mathrm{~m}, 10 \mathrm{~m}$ \\
\hline
\end{tabular}

\section{2 実験結果}

本実験においては、過剩間隙水圧、変位量、加速度、地中壁の土 圧およびひずみを計測しているが、本論では、液状化の程度を示す 指標として、過剩間隙水圧から求めた過剩間隙水圧比を用いる。計 測した過剩間隙水圧を地中の鉛直応力（上載圧による鉛直応力と地 盤の自重による有効土被り圧の和）で除して求めた過㮃間隙水圧比 の時刻歴を図 14 に、表 2 にそれぞれケースの最大間隙水圧比の值 を示す。

図 14 の上段 $(\mathrm{a}$ ）は、液状化層厚が $10 \mathrm{~m}$ の場合であり、下段 $(\mathrm{b}$ ) は液状化層厚が $5 \mathrm{~m}$ の場合である。過剩間隙水圧は、液状化層厚が $10 \mathrm{~m}$ の場合は 3 深度で、液状化層厚が $5 \mathrm{~m}$ の場合は 2 深度で計測し ている。図の左より、格子間隔 $3 \mathrm{~m} 、 5 \mathrm{~m} 、 10 \mathrm{~m}$ の結果を地表面から の深さ毎に上から並べて示した。それぞれの時刻歴図内では、地表 面の上載圧 $\left(0 \mathrm{kN} / \mathrm{m}^{2} 、 30 \mathrm{kN} / \mathrm{m}^{2} 、 60 \mathrm{kN} / \mathrm{m}^{2}\right)$ をパラメータとして 重ねて記載している。

表 2 各ケースの最大過剩間隙水圧比

\begin{tabular}{|c|c|c|c|c|c|}
\hline \multirow{2}{*}{ 層厚 } & \multirow{2}{*}{ 樑度 } & \multirow{2}{*}{ 上載圧 } & \multicolumn{3}{|c|}{ 格子間隔 } \\
\hline & & & $3 \mathrm{~m}$ & $5 \mathrm{~m}$ & $10 \mathrm{~m}$ \\
\hline \multirow{9}{*}{$10 \mathrm{~m}$} & \multirow{3}{*}{$2 \mathrm{~m}$} & $0 \mathrm{kN} / \mathrm{m}^{2}$ & 1.00 & 1.00 & 1.00 \\
\hline & & $60 \mathrm{kN} / \mathrm{m}^{2}$ & 0.48 & 0.42 & 0.83 \\
\hline & & $(60 / 0)$ & $(0.48)$ & $(0.42)$ & $(0.83)$ \\
\hline & \multirow{3}{*}{$5 \mathrm{~m}$} & $0 \mathrm{kN} / \mathrm{m}^{2}$ & 0.80 & 0.68 & 1.00 \\
\hline & & $60 \mathrm{kN} / \mathrm{m}^{2}$ & 0.51 & 0.41 & 0.62 \\
\hline & & $(60 / 0)$ & $(0.65)$ & $(0.60)$ & $(0.62)$ \\
\hline & \multirow{3}{*}{$8 \mathrm{~m}$} & $0 \mathrm{kN} / \mathrm{m}^{2}$ & 0.61 & 0.47 & 0.70 \\
\hline & & $60 \mathrm{kN} / \mathrm{m}^{2}$ & 0.52 & 0.41 & 0.46 \\
\hline & & $(60 / 0)$ & $(0.85)$ & $(0.87)$ & $(0.65)$ \\
\hline \multirow{6}{*}{$5 \mathrm{~m}$} & \multirow{3}{*}{$1.5 \mathrm{~m}$} & $30 \mathrm{kN} / \mathrm{m}^{2}$ & 0.37 & 0.35 & 0.70 \\
\hline & & $60 \mathrm{kN} / \mathrm{m}^{2}$ & 0.31 & 0.33 & 0.35 \\
\hline & & $(60 / 30)$ & $(0.85)$ & $(0.94)$ & $(0.50)$ \\
\hline & \multirow{3}{*}{$3.5 \mathrm{~m}$} & $30 \mathrm{kV} / \mathrm{m}^{2}$ & 0.28 & 0.25 & 0.47 \\
\hline & & $60 \mathrm{kV} / \mathrm{m}^{2}$ & 0.34 & 0.29 & 0.32 \\
\hline & & $(60 / 30)$ & $(1.19)$ & $(1.13)$ & $(0.68)$ \\
\hline
\end{tabular}

() 内は、中段の上載圧の大きなケースの最大過剰間隙水圧 比を、上段の上載圧の小さなケースのそれで除した值。

\section{（1）上載圧の大小による液状化抑制効果の相違}

図 14 のいずれのケースにおいても、上載圧がない $\left(0 \mathrm{kN} / \mathrm{m}^{2}\right)$ 場 合に比べて、上載圧がある $\left(60 \mathrm{kN} / \mathrm{m}^{2}\right)$ 場合の方が、過剩間隙水圧 比が小さくなっており、上載圧が液状化を抑制する効果が明確に表 れている。有効拘束圧（上載圧+土被り）の大きい方が、過剩間隙 水圧比は小さくなる傾向にあるが、格子間隔や深度によりその影響
は異なり、格子間隔が $10 \mathrm{~m}$ と最も広いケースでは、明確に有効拘束 圧の大小が過剩間隙水圧比の大きさに表れているのに対して、格子 間隔が狭く深い深度ほど上載圧の大小による過剩間隙水圧比の差は 小さい。これは、過剩間隙水圧比が小さい範囲では有効拘束圧の大 小による影響が出にくいことや、格子間隔が狭い場合に深い深度で は上載圧が伝わりにくいことなどによるものと考えられる。

\section{（2）地中壁格子間隔の上載圧による液状化抑制効果への影響}

表 2 の（）に示した上載圧による過剩間隙水圧比抑制効果の度合 いを示す值（上載圧の大きいケースの過剩間隙水圧比を上載圧の小 さいケースのそれで除した值）に着目寸ると、層厚 $10 \mathrm{~m}$ において、 格子間隔 $10 \mathrm{~m}$ の $-2 \mathrm{~m}$ では、 0.83 と格子間隔 $3 \mathrm{~m}, 5 \mathrm{~m}$ と比べ大きな值 （液状化抑制効果の度合いが小さい）となっている。過剩間隙水圧 比は 1.0 が上限であることから、単純に浅い位置で格子間隔が広い 場合は、上載圧による過剩間隙水圧比の低減効果が小さいとは言え ないが、深い位置の- $8 \mathrm{~m}$ では明確に格子間隔 $3 \mathrm{~m}, 5 \mathrm{~m}$ よりも大きな 低減効果となっている。このことは、せん断変形抑制効果が低い格 子間隔が広い場合においても、上載圧により大きな過剩間隙水圧比 抑制効果が得られることを示している。

\section{（3）液状化層厚の上載圧による液状化抑制効果への影響}

液状化層厚に着目し、図 14 の（ a ）と（b）を比較すると、液 状化層厚が厚い場合 $(\mathrm{a}: 10 \mathrm{~m})$ の方が、層厚が薄い場合 $(\mathrm{b}: 5 \mathrm{~m})$ よりも、総じて過剩間隙水圧比が大きく、液状化の程度が大きいこ とが明確に表れている。層厚が異なれば、入力地震動に対する応答 自体も異なるため、単純な結論付けはできないが、液状化層厚が厚 い場合は、上載圧の影響をより深くまで伝達する必要があるため、 層厚が厚くなれば、より大きな上載圧が必要となると考えられる。

\section{（4）上載圧による液状化抑制効果に対する深度の影響}

図 14 の液状化層厚の厚い（a）について、深度毎の過剩間隙水 圧比に着目すると、深い深度では、上載圧がない場合も過剩間隙水 圧比が 1 を下回り、液状化に達していない。これは格子状地中壁の せん断変形抑制効果によるものと考えられる。しかしながら、その 場合も、地表面付近の浅い位置では、液状化に至っており、格子間 隔が狭い場合も地表面付近では、液状化を抑制しきれない場合があ ることが分かる。一方、上載圧による液状化抑制効果は、鉛直応力 が伝達しやすい浅い深度ほど効果が高く、深い深度ほど鉛直応力が 伝達しにくいため効果を発揮するためにより大きな上載圧が必要と なる。このことからも、上載圧による液状化抑制効果と地中壁によ るせん断変形抑制効果の併用が、両者の不利な点を補完することが 出来る合理的な対策手法であるといえる。

\section{（5）地中壁による基礎の沈下抑制効果}

図 15 に地中壁の有無による基礎の沈下量の比較を示す。実験パ ラメータは、上載圧 $60 \mathrm{kN} / \mathrm{m}^{2}$ 、液状化層厚 $10 \mathrm{~m}$ である。図では、 格子間隔の違う 3 ケースとそれに対応する基礎寸法の地中壁がない 3ケースについて示している。

いずれの格子間隔（基礎寸法）でも、地中壁がない場合に 150〜 $200 \mathrm{~mm}$ の過大な沈下が生じていたのに対して、地中壁がある場合 は、10 20mm 程度の沈下量となっており、大幅に沈下量が低減さ れている。また、加振終了の 120 秒時点において、地中壁のある場 合には、ほぼ沈下が落ち着いており、沈下量の増加傾向が見られな いのに対して、地中壁がない場合は増加傾向が見られる。 

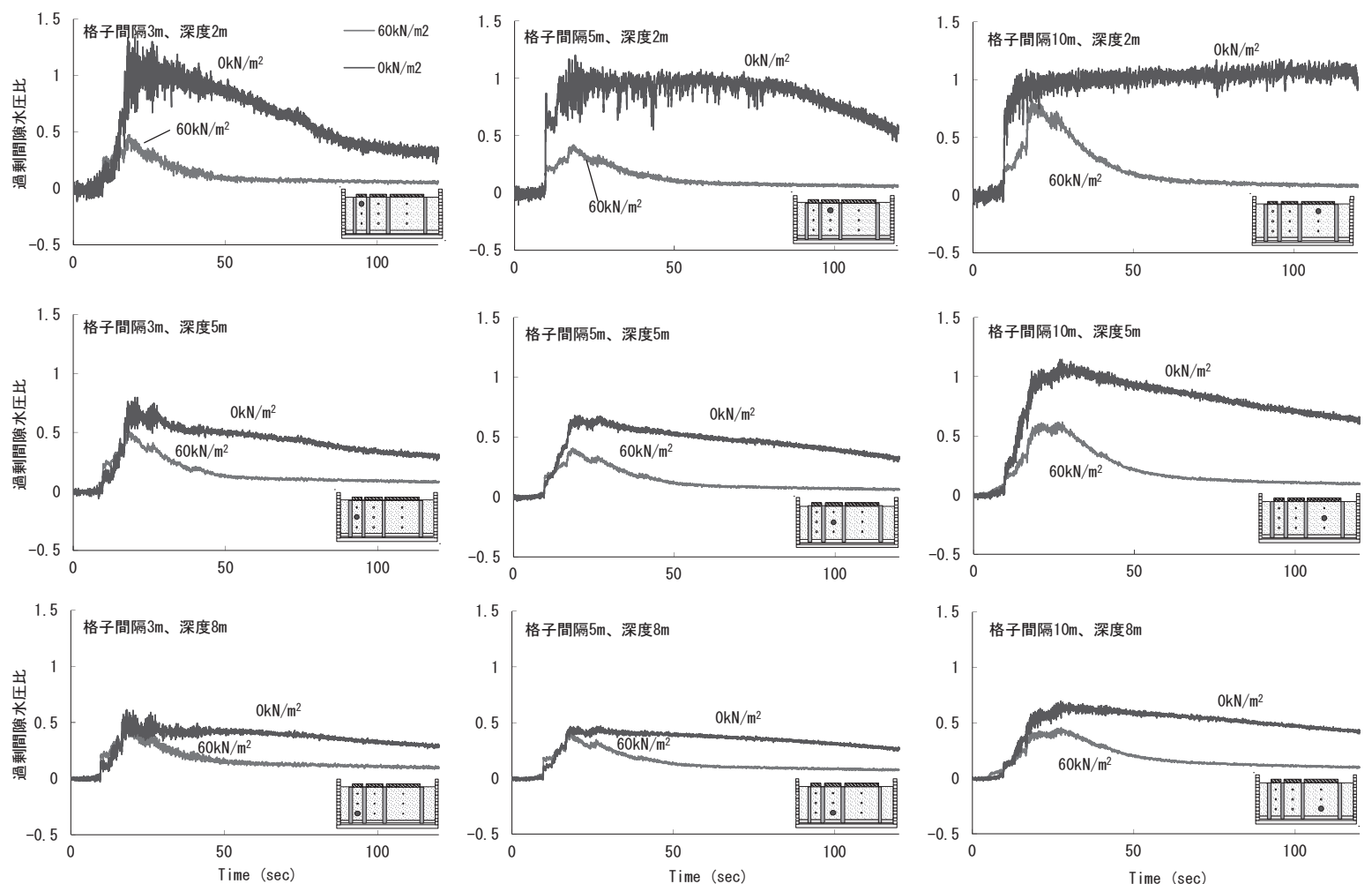

(a ) 液状化層厚 $10 \mathrm{~m}$
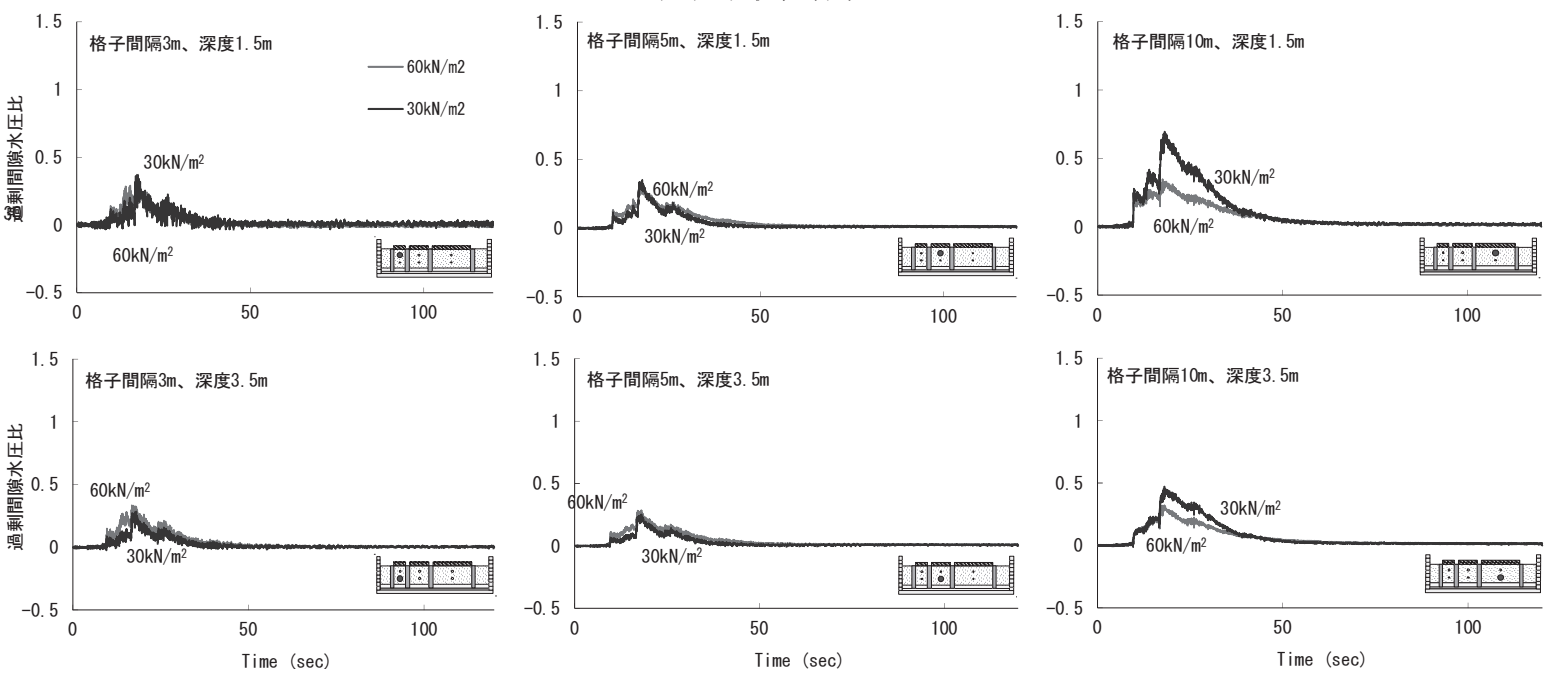

(b) 液状化層厚 $5 \mathrm{~m}$

図 14 過剩間隙水圧比の時刻歴

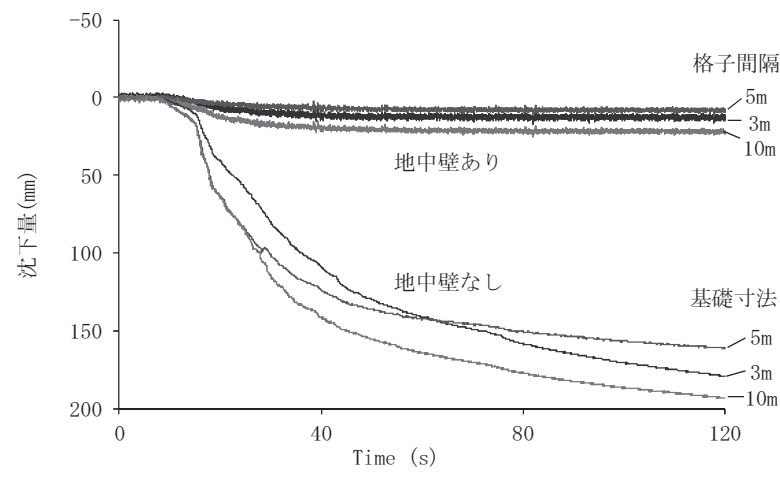

図 15 地中壁の有無による基礎の沈下量の比較

以上より、地中壁が存在すると基礎の沈下量は、大幅に低減する ことが確認できる。

格子間隔の違いよる沈下量への影響について着目すると、格子間 隔（基礎寸法）が最も広い $10 \mathrm{~m}$ の場合で、基礎の沈下量が大きくな っているものの、格子間隔（基礎寸法） $3 \mathrm{~m} 、 5 \mathrm{~m}$ の場合では、 $3 \mathrm{~m}$ の場合の方が、 $5 \mathrm{~m}$ よりも大きな沈下量となっており、格子間隔（基 礎寸法）と基礎の沈下量の相関関係は、必ずしも明確ではない。

一方上載圧が $60 \mathrm{kN} / \mathrm{m}^{2}$ で地中壁がある場合も、格子間隔 $10 \mathrm{~m}$ の場 合には地表面近くで過剩間隙水圧比が上昇し、液状化に近い状態に なっている（図 14）。これは格子間隔 $10 \mathrm{~m}$ の場合が最も沈下量が大 きくなった要因の一つと考えられ、地中壁がある場合も直下地盤の 液状化が抑制されていないと沈下量が増大寸ることを示唆している。 


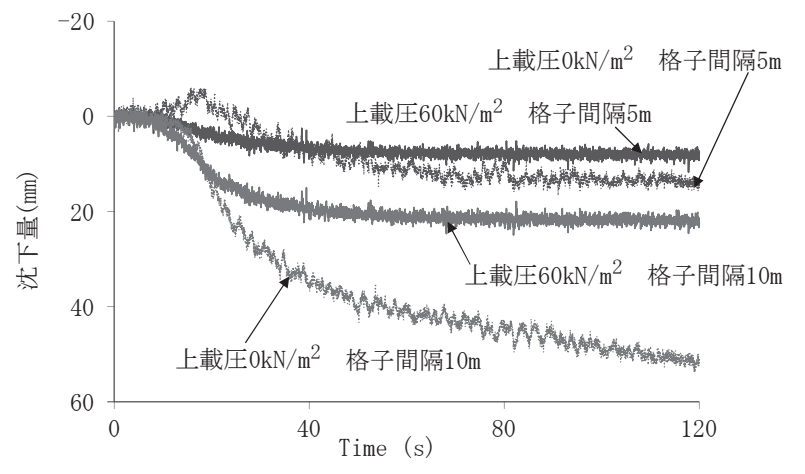

図 16 上載圧の有無による基礎の沈下量の比較

図 16 に地中壁を設けた実験ケースにおける上載圧の有無による 基礎沈下量の比較（上載圧の無いケースでは地表面の沈下量）を示 す。格子間隔 $5 \mathrm{~m} 、 10 \mathrm{~m}$ ともに上載圧の有る方が、沈下量を抑えら れる結果となっている。レーザー変位計の計測点が地表面より沈下 していた可能性もあるが、上載圧による液状化抑制効果により過剰 間隙水圧比の上昇が抑えられ、地盤剛性の低下を抑制できたことに よるものと考えられる。

\section{3 シミュレーション解析}

遠心力載荷実験の結果より、上載圧による液状化抑制効果と格子 状地中壁を併用することで、合理的に液状化対策が行えると考えら れる。この液状化対策手法の設計を行うためには、解析的に液状化 抑制効果を再現できることが重要である。このことから、遠心力載 荷実験のシミュレーション解析を行い、結果について検討を行った。

\section{(1) 解析方法}

シミュレーション解析は、二次元 FEM モデルを用いた。解析プ ログラムは、 2 章のシミュレーション解析と同様である。力学的境 界条件は、解析モデル底面を固定境界、側方は周期境界とした。

図 17 に解析モデル図を、図 18 に解析に用いた液状化強度曲線を 示寸。液状化強度曲線は、2.3(1)(2) と同様に豊浦砂の相対密度 $60 \%$ の強度曲線を想定し、 $\mathrm{K}_{0}=0.5$ を考慮して原位置強度比に変換したも のを用いた。格子状地中壁の剛性は、谷崎らの文献 22) より、 $\mathrm{E}=3350 \mathrm{MN} / \mathrm{m}^{2}$ 、ポアソン比 $v=0.35$ を用いて評価した。

直接基礎は、上載圧相当の荷重を持つ梁要素としてモデル化し、 地盤には土被り圧を初期応力として与え、上載圧による鉛直載荷解 析を行った後、鋁直載荷により生じた過剩間隙水圧の消散を待って、 応答解析を行った。

図 19 に鉛直載荷解析後の初期応力 ( $\left.\sigma \mathrm{vo}^{\circ}\right)$ のコンター図を示寸。 地中壁間隔の狭い方が広い場合と比べ、地中壁との摩擦の影響で深 い位置での初期有効上載圧が小さくなっている。

直接基礎の梁要素端部と面外壁天端の間には、実験と同様にクリ アランス（格子内地盤と同様の材料特性）を設けた。実験では奥行 方向においてもクリアランスを設けており、どの格子幅のケースで も奥行方向の間隔は同じである。このため、直接基礎の梁要素部分 は排水条件とし、どの格子間でも排水し易さが同程度となるように 配慮した。その他の部分においては、解析モデル上面の地盤部分は 排水条件とし、側方の排水条件は周期境界条件、底面は非排水条件 とした。透水係数は、 $0.0006 \mathrm{~m} / \mathrm{sec}$ を用いた。

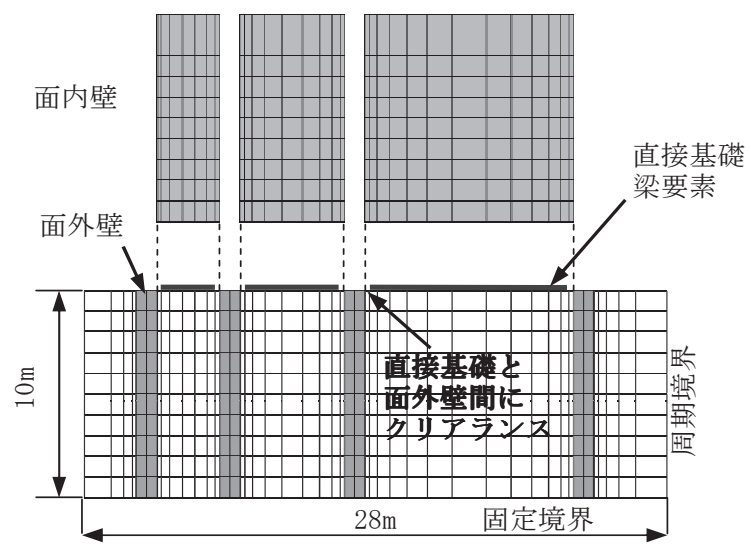

図 17 二次元 FEM モデル図

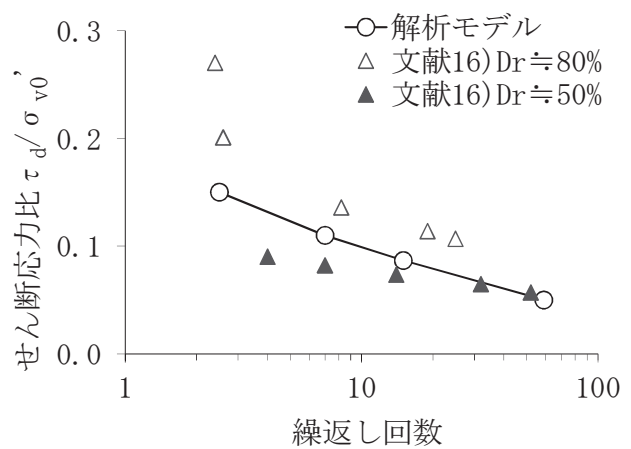

図 18 液状化強度曲線のモデル化（初期有効上載圧 $98 \mathrm{kN} / \mathrm{m}^{2}$ )

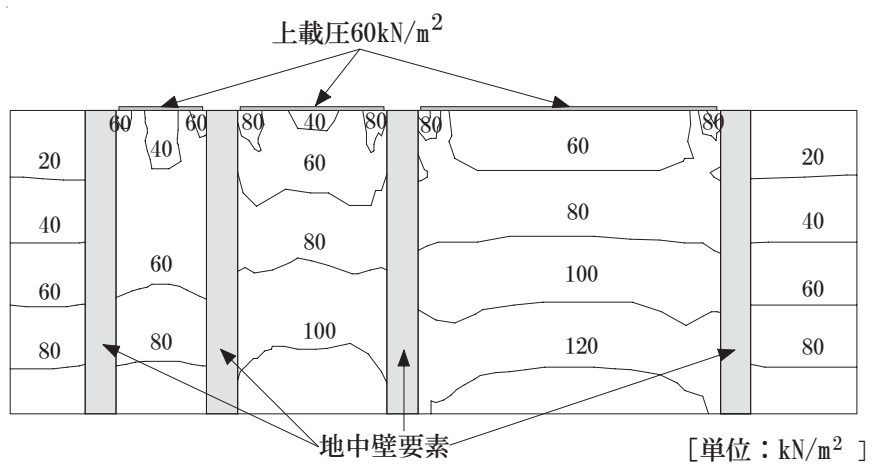

図 19 初期応力（ｏｒｏ） のコンター図

\section{（2）解析結果}

図 20 に層厚 $10 \mathrm{~m}$ の実験ケースにおける上載压 $0 \mathrm{kN} / \mathrm{m}^{2}$ と上載圧 $60 \mathrm{kN} / \mathrm{m}^{2}$ のケースの過剩間隙水圧比の解析結果と実験結果の比較 を示す。解析は、格子間隔 $3 \mathrm{~m}$ 部分もモデル化しているが、図では 格子間隔 $5 \mathrm{~m}$ と $10 \mathrm{~m}$ の結果について記載している。上載圧 $0 \mathrm{kN} / \mathrm{m}^{2}$ では、解析結果の過㮃間隙水圧の消散がやや早い傾向があるが、概 ね実験結果を再現している。一方、上載圧 $60 \mathrm{kN} / \mathrm{m}^{2}$ では、格子間隔 $10 \mathrm{~m}$ の解析結果において、30 秒以降も過剩間隙水圧比の上昇が見 られ、過剩間隙水圧比を大きめの安全側に評価しているが、格子間 隔が広い方が、過剩間隙水圧比が高くなることや深い深度ほど過剩 間隙水圧比が低くなることを概ね再現している。 

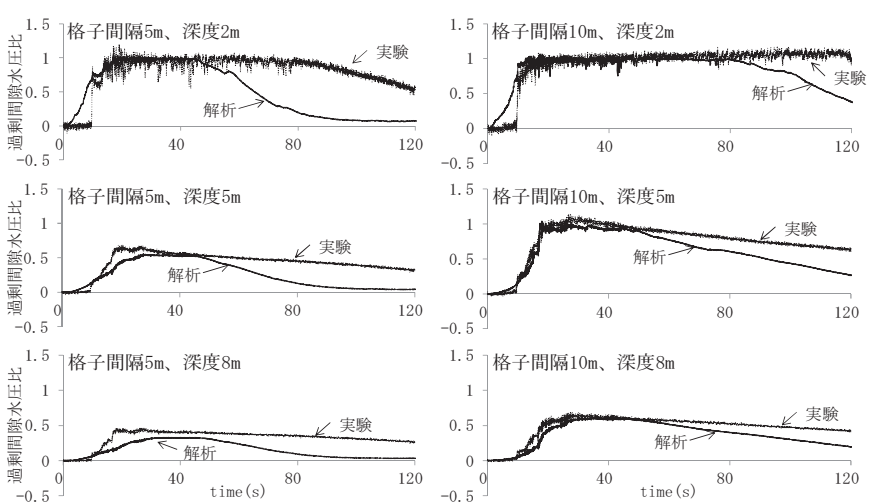

( a ) 上載圧 $0 \mathrm{kN} / \mathrm{m}^{2}$
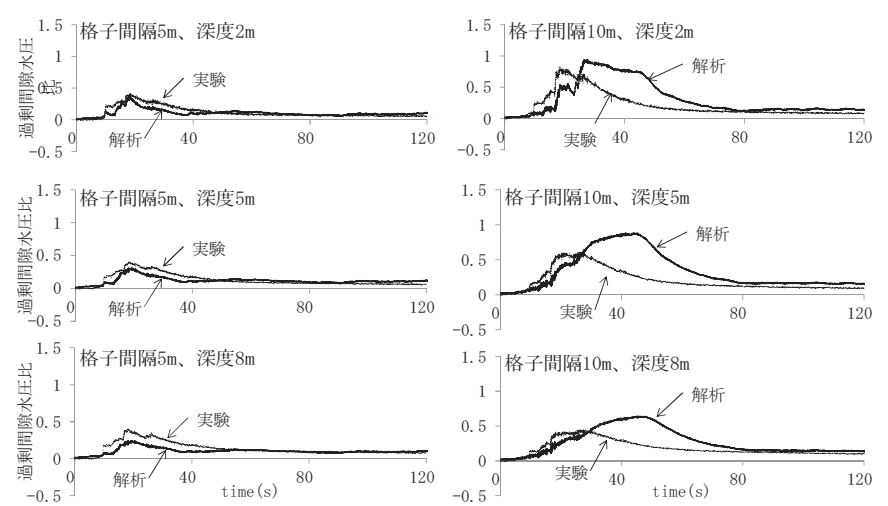

(b) 上載圧 $60 \mathrm{kN} / \mathrm{m}^{2}$

図 20 過剰間隙水圧比時刻歴の解析結果と実験結果

\section{（3）既往のせん断応力推定式の適用性}

液状化強度比に対する格子状地中壁の影響がないと考えると、繰 返しせ几断応力比を評価出来れば、上載圧による液状化抑制効果と 格子状地中壁の併用による液状化対策を行った地盤の液状化危険度 を簡易的に評価できると考えられる。格子状地中壁による液状化対 策を行った地盤における繰返しせん断応力比を評価する方法として、 FL 法の繰返しせん断応力比を、格子間隔などに応じた係数で補正 する手法が、田屋らによって提案されている23)が、基礎からの建物 慣性力によるせん断力の伝達は考慮されておらず、上載圧による液 状化抑制効果と格子状地中壁の併用による液状化対策地盤には、そ のまま適用できないと考えられる。

ここでは、解析結果の格子内地盤のせん断応力を用いて、基礎指 針のせん断応力推定式（地中壁と上載圧未考慮）12)および田屋らの 評価式 ${ }^{23)}$ による結果との比較を行い、既往式の適用性について検討 を行った。なお、解析結果は有効応力解析による結果を用いている が、最大せん断応力は過剩間隙水圧比が上がりきって液状化が発生 する前で生じており、液状化による影響は少ないと考えられる。ま た、基礎指針のせん断応力推定式 ${ }^{12)}$ と田屋らの評価式 23)による結果 は、解析結果の各上載圧における地表面加速度の值を用いているた め、各上載圧で異なる結果となっている。

図 21 に各上載圧における最大せん断応力比の深度分布を示す。 解析結果の最大せん断応力比は、上載圧が大きくなるにしたがって、 いずれの格子間隔でも小さくなる傾向にある。これは、上載圧によ り、有効鉛直応力は上載圧の荷重分が増加するのに対して、せん断 応力は上載圧に水平震度を乗じた慣性力分のみ増加するためである

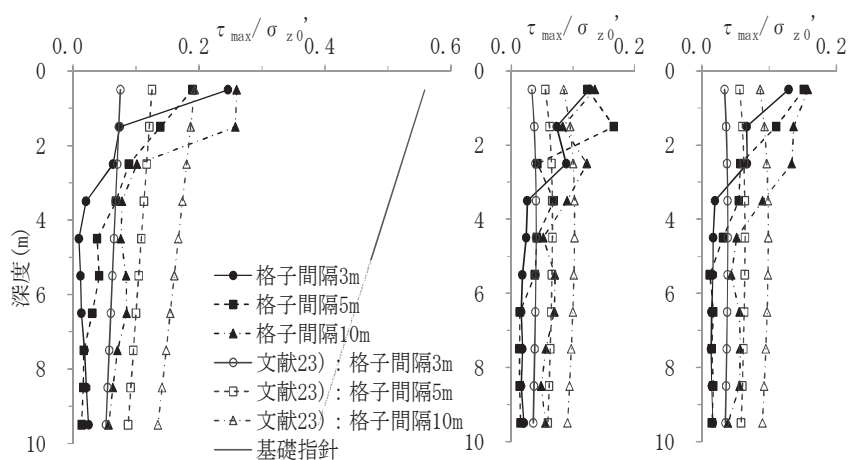

(a ) $0 \mathrm{kN} / \mathrm{m}^{2}$

(b ) $30 \mathrm{kN} / \mathrm{m}^{2}$

(c ) $60 \mathrm{kN} / \mathrm{m}^{2}$

図 21 最大せん断応力比の比較

と考えられる。

既往式によるせん断応力比と解析結果の比較では、基礎指針式によ る最大せん断応力比は、上載圧 $0 \mathrm{kN} / \mathrm{m}^{2}$ においても解析結果を大きく 上回っている。これは格子状地中壁による格子内地盤のせん断変形 抑止効果が考慮されていないためと考えられる。一方、文献 23)式 による最大せん断応力比は、上載圧がない場合 $\left(0 \mathrm{kN} / \mathrm{m}^{2}\right)$ では、地 表面で過小評価となっているが、- $1.5 \mathrm{~m}$ 以深では若干大きいものの 安全側の值となっており、実務上問題はないように思われる。しか し、上載圧のある場合では、地表面の過小評価となる範囲が拡大し、 $-3.5 \mathrm{~m}$ 付近までせん断応力比を過小評価している。これは、地表面 に上載圧（建物重量）の慣性力によるせん断応力が生じることによ る影響と考えられ、上載圧による液状化抑制効果と格子状地中壁の 併用による液状化対策を行った地盤の実務設計においては、上載圧 (建物重量) の慣性力によるせん断応力を考慮してせん断応力比を 算定する必要があると考えられる。

\section{4. 結論}

直接基礎構造物を模擬した遠心力載荷実験、直接基礎と格子状地 中壁を模擬した遠心力載荷実験の結果およびそれらのシミュレーシ ヨン解析結果より、直接基礎の上載圧による液状化抑制効果につい て、検討および考察を行った。得られた知見を以下に示す。

（1）直接基礎の上載圧により、直接基礎直下地盤の過剩間隙水圧比 の上昇が抑えられる。

（2）直接基礎の上載圧による液状化抑制効果は、基礎に近い浅い深 度ほど顕著であり、深度が深くなれば効果が小さくなる。

（3）直接基礎の上載圧による液状化抑制効果は、上載圧が大きいほ ど効果が高い。

（4）直接基礎の上載圧により、基礎直下地盤の液状化を抑制できた 場合でも、周辺地盤の液状化に伴い、基礎直下地盤の水平方向の はらみだしが生じ、基礎に過大な沈下が起こるが、これは格子状 地中壁を設けることで大幅に抑制できる。

（5）直接基礎からの建物慣性力による地中へのせん断応力を考慮 した簡易的な液状化危険度の評価は、深度方向に半無限円錐で増 加する影響面積を仮定した手法で概ね評価できる。

（6）格子状地中壁によるせん断変形抑制効果が得られ難い格子間 隔が広い場合においても、直接基礎の上載圧による液状化抑制効 
果を併用することで、液状化の発生を抑止できる。

（7）直接基礎と格子状地中壁を模擬した遠心力載荷実験の実験結 果は、二次元有効応力解析によるシミュレーション解析で、概ね 再現できる。

本論で示した遠心力載荷実験は、液状化の生じやすい細粒分含有 率ゼロの豊浦砂で行っており、細粒分含有率の比較的多いシルト混 じり砂地盤などでの、上載圧による液状化抑制効果については、更 なる検討が必要と思われが、地震時に液状化が観測されたシルト層 についても、拘束圧による液状化強度の増加が報告されており ${ }^{24)}$ 、 上載圧による液状化抑制効果は得られると考えられる。

本論で示した液状化対策手法を、実施適用するにあたっては、地 中壁と格子内地盤の摩擦力による上載圧の低減に対する方策、地中 壁の応力検討、基礎の沈下の評価、せん断応力の簡易的な評価手法 の検討、実スケールモデル実験での検証や細粒分 Fc が大きい砂地盤 での過剩間隙水圧の蓄積に対する検討などの課題も多い。これらに ついては、今後、継続して検討を行う予定である。

\section{参考文献}

1）山田雅一: 2.1 首都圏における液状化被害状況, 日本大学理工学部理工 学研究所研究ジャーナル．2011，pp. 125_4-125_9, 2011.10

2）日本建築学会: 建築基礎のための地盤改良設計指針案, pp. 100-117, 2006

3）千葉県環境研究センター：平成 23 年（2011 年）東北地方太平洋沖地震 における千葉県内の液状化一流動化被害（第 2 報），2011.4

4）吉見吉昭：砂地盤の液状化（第二版），技報堂出版，pp. 32-34，1991

5) Yoshimi, Y. and Tokimatsu, K. : Settlement of buildings on saturated sand during earthquakes, Soils and Foundations, Vol.17, No.1, pp. 23-38, 1977. 3

6) Liu, L. and Dobly, R. : Seismic response of shallow foundation on liquefiable sand, Journal of Geotechnical and Geoenvironmental Engineering, pp. 557-567, 1997.6

7）藤原斉郁, 堀越研一, 安田進, 河村直明: 液状化による直接基礎の沈下 に関する遠心載荷模型実験, 土木学会第 57 回年次学術講演会, pp. 1037-1038，2002.9

8）吉富宏紀, 原田健二, 出野智之, 安達俊夫, 山田雅一, 原寛武: 液状化 地盤および締固め改良地盤上の直接基礎の沈下挙動, 第 39 回地盤工学研究 発表会（新潟），pp. 1823-1824，2004.7

9）船原英樹, 柴田景太, 長尾俊昌：直接基礎近傍の飽和砂層における間隙 水圧の地震時挙動, 日本建築学会大会学術講演梗概集, B-1, pp. 439-440, 2010.9

10）日本建築防災協会: 臨海部における大規模建築物群の総合的な構造安全 に関する調査・検討のうち「動的設計用入力地震動の設定に関する検討」 報告書, 1992

11）地盤工学会：基礎の沈下予測と実際，p. 69，2000.

12）日本建築学会 : 建築基礎構造設計指針, pp. 61-72, 2001

13）石原研而：土質動力学の基礎, 鹿島出版会, pp. 249-250, 1976

14）ソフトウェアサイエンス研究所 : DIANA-J 概要書 Version. 2. 0, 1987

15) Misko, C. and Ishihara, K. : Modelling of sand behaviour based on state concept, Soils and Foundations, Vol. 38, No. 3, pp. 115-127, 1998. 9

16）吉見吉昭：砂地盤の液状化（第二版），技報堂出版，pp. 75-77，1991

17) Okochi, Y. and Tatsuoka, F. : Some factors affecting K0-values of sand measured in triaxial cell, Soils and Foundations, Vol.24, No. 3, pp. 52-68, 1984.9

18）日本建築学会: 建物と地盤の動的相互作用を考慮した応答解析と耐震設 計, pp. 127-131, 2006

19) Toki, S., Tatsuoka, F., Miura, S., Yoshimi, Y., Yasuda, S. and Makihara, Y. : Cyclic undrained triaxial strength of snad by a cooperative test program, Soils and Foundations, Vol.26, No.3, pp. $117-128, \quad 1986.9$
20) Tokimatsu, K. and Yoshimi, Y. : Empirical correlation of soil liquefaction based on spt $\mathrm{N}$-value and fines content, Soils and Foundations, Vol.23, No. 4, pp. 56-74, 1983. 10

21）谷口栄一, 古賀泰之, 森下義 : 周辺地盤の液状化による地中構造物の浮 上りの安全率の評価法, 土木学会第 40 回年次学術講演会梗概集 III, pp. $79-80,1985.9$

22）谷崎史織，立石章，宇野浩樹：遠心模型実験による格子状改良地盤の液 状化抑止効果と壁体に作用する土圧の評価，土木学会論文集 C, Vol.66, No. 1, pp. 156-171，2010. 3

23）田屋裕司, 内田明彦, 吉澤睦博, 鬼丸貞友, 山下清, 津國正一：格子状 地盤改良における格子間隔の簡易設定法，地盤工学ジャーナル，Vol. 3, No. 3, pp. 203-212, 2008. 11

24）松下怜, 森伸一郎, 岡崎健 : 種々の拘束圧下での竹内シルトの液状化特 性, 第 30 回地盤工学研究発表会, pp. 353-354, 2004.7

(2012年 4 月 9 日原稿受理， 2012年 8 月 3 日採用決定） 